\title{
Photocatalytic Degradation of Synthetic Textile Effluent by Modified Sol-Gel, Synthesized Mobilized and Immobilized $\mathrm{TiO}_{2}$, and Ag-doped $\mathrm{TiO}_{2}$
}

\author{
Tayyaba Muhammad Akram ${ }^{1,3 *}$, Nasir Ahmad ${ }^{2}$, Irfan Ahmad Shaikh ${ }^{1}$ \\ ${ }^{1}$ College of Earth and Environmental Sciences, University of the Punjab, Lahore 5459, Pakistan \\ ${ }^{2}$ Institute of Geology, University of the Punjab, Lahore 5459, Pakistan \\ ${ }^{3}$ Department of Science Education (IER), University of the Punjab, Lahore 54590, Pakistan
}

Received: 4 February 2016

Accepted: 7 March 2016

\begin{abstract}
Advanced oxidation processes (AOPs) have proven to be very effective for treating various hazardous organic pollutants in water. The present study uses a double-walled horizontal glass reactor (DHGR) to investigate heterogeneous $\mathrm{UV} / \mathrm{TiO}_{2}$ (titanium dioxide) and $\mathrm{UV} / \mathrm{Ag}-\mathrm{TiO}_{2}$ (mobilized and immobilized) photocatalytic degradation of synthetic textile effluent (Remazol Red RGB) with UV (400W). The textile effluent was characterized in terms of $\mathrm{pH}$, chemical oxygen demand (COD), and degree of decolorization (at $519 \mathrm{~nm}$ ) before and after treatment. Optimum degradation results were obtained at $\mathrm{pH} 3$. We also found that with different catalysts and catalyst doses, the rate of degradation rises up to a maximum "critical" value. The electron scavenger was Ag-led to a faster degradation of synthetic textile effluent in the photocatalytic system. The photocatalytic degradation proved to be dependent on the effluents' initial COD, catalyst dose, catalyst form, and $\mathrm{pH}$ of the medium. Results reveled that among different forms of catalysts, $\mathrm{Ag}_{-} \mathrm{TiO}_{2}(\mathrm{Mesh})$ and $\mathrm{TiO}_{2}(0.5 \mathrm{~g})$ showed better $\mathrm{COD}$ percentage and $\mathrm{ABS}$ percentage removal at $\mathrm{pH} 3$ with initial concentrations of synthetic effluent $560 \mathrm{mg} / 1$ under UV(400W) irradiation.
\end{abstract}

Keywords: photo catalytic degradation, $\mathrm{TiO}_{2}$ and $\mathrm{Ag}-\mathrm{TiO}_{2}$ catalysts, synthetic textile effluent

\section{Introduction}

The textile industry generates wastewaters of immense chemical complexity, diversity, and volume because of the use of a great variety of fibers, dyes, process aids, and finishing products [1-3]. The dyes, organic pollutants,

*e-mail: tmabpu@hotmail.com and their intermediates present in textile effluent with high aromaticity and low biodegradability, which poses a serious threat to the ecological system when released untreated into water bodies. Hence this situation demands treatment of the textile wastewaters before their disposal [4-7]. A variety of techniques, ranging from conventional treatment methods to the most sophisticated techniques like advanced oxidation processes (AOPs), are in practice to clean textile wastewater [8-11]. AOPs have the ability 
to degrade calcitrant organic pollutants to $\mathrm{CO}_{2}$ and water, so that consequently there is no mass residue [12-14]. However, there are some organic pollutants that are persistent in nature and are not completely mineralized by common AOPs, and their treatment leads to the production of highly toxic byproducts of low biodegradability [1517]. Hence researchers have given special emphasis to the photocatalysis process because of its advantage to effectively reduce the production of byproducts [18-20].

Titanium dioxide $\left(\mathrm{TiO}_{2}\right)$ is the most widely used catalyst due to its distinct environment-friendly nature [21-23]. Attempts have been made to improve the overall efficiency of $\mathrm{TiO}_{2}$ [24-25]. One way to enhance the performance of the catalyst is to dope $\mathrm{TiO}_{2}$ matlrix with transition metals (Pt, Au, Ag), because co-metals can improve the photoactivity of $\mathrm{TiO}_{2}$ [26-28].

A variety of photocatalytic reactors are used in research applications [29-33]. Birnie et al. [34] have extensively reviewed the photocatalytic reactors currently in use. Caliman and Balasanian [35] and Serrano et al. [36] have reported the performance of the reactor as a function of its dimension. However, photocatalytic reactors that provide better configuration to maximize efficiency of photon utilization are considered suitable [37-39].

The present research work is mainly focused on the design, manufacture, and commissioning of laboratoryscale photocatalytic reactors. A two-pronged strategy was followed to accomplish the task. Firstly, the catalyst was synthesized and doped with co-metals. Secondly, the photocatalysis process was optimized in terms of process conditions, including $\mathrm{pH}$, temperature, catalyst dose, catalyst type, and reactor [40-41].

\section{Materials and Methods}

The photocatalytic oxidation setup was developed in terms of design, fabrication, and construction of the reactor, whereas the experimental process was optimized in terms of catalyst synthesis and process conditions such as $\mathrm{pH}$, temperature, dose, and exposure time.

\section{Reactor Design and Fabrication}

\section{Materials Used}

The materials used in the reactor fabrication were mainly glass no more than one-half inch thick and a quartz tube and liquid silcon. The reactor was constructed at laboratory scale.

\section{Double-walled Horizontal Glass Reactor}

The apparatus consisted of:

- 400W UV lamps (Shanghai JWFU Industry Co., Ltd. China);

- Automatic voltage stabilizer (Supreme Bolster, input-135-250 VAC, output $220 \pm 5 \%, 2000 \mathrm{~W}$ ) to regulate the voltage of the UV lamps;

- Blast (Shanghai JWFU Industry Co., Ltd.China);

- Magnetic stirrer (78-1 Megnetic stirrerhotplate, 0-1400 rpm) for continuous mixing of the textile effluent;

- Stool to elevate the reactor off the ground;

- Switchboard for electrical supply.

Our novel double-walled horizontal glass reactor (NDHGR) (Fig. 1) was designed and constructed to be suitable for UV-assisted photocatalytic degradation of the textile effluent. The UV lamps (A) had $400 \mathrm{~W}$ of power. The reactor was composed of three parts:

- Outer compartment with $18 \times 12$ (B x C) inches 6.3 (D) inches height;

- The middle compartment of 9 x 12(E x F) inches with $6.3(\mathrm{G})$ inches height having capacity of 1-6 liters, which is designed to carry out photocatalytic reaction. This compartment is placed in center of the larger compartment, which is designed to contain water to maintain the temperature of the photocatalytic reaction;

- Lower compartment $(\mathrm{H})$ for the magnetic stirrer. The double wall served to circulate water to maintain its temperature between $29-32^{\circ} \mathrm{C}$. The lamp, along with its holder, is placed on top of the middle compartment. The total height of both parts in total was 12 inches.
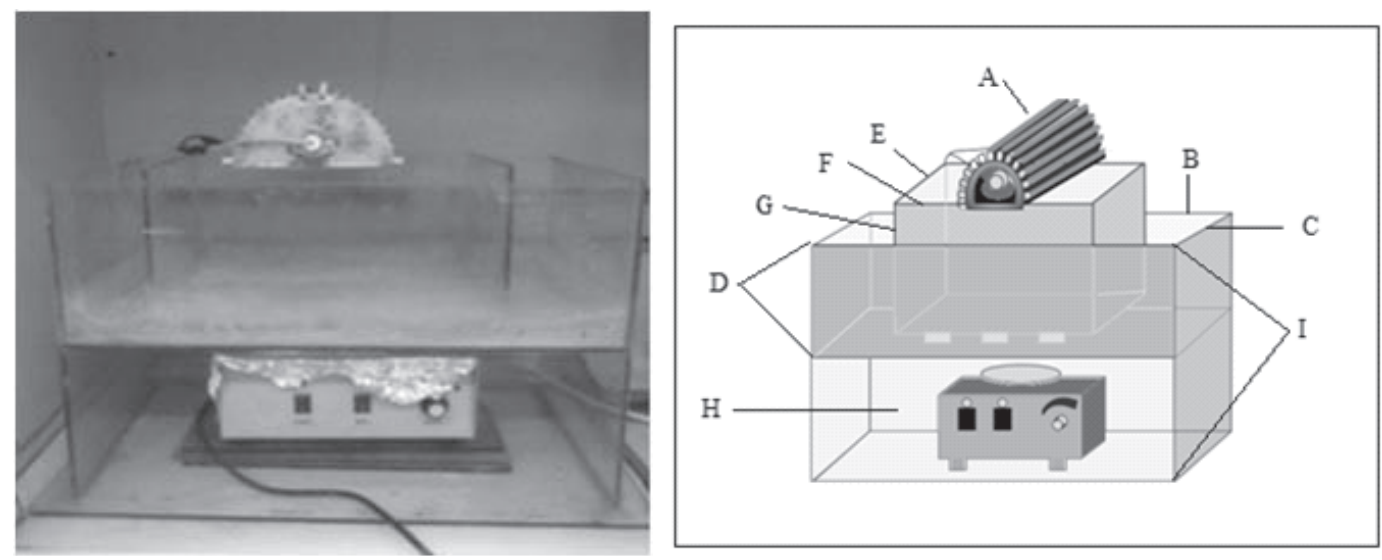

Fig. 1. The double-walled horizontal glass reactor (DHGR) designed for the UV-assisted treatment of synthetic textile effluent (Remazol Red RGB). 


\section{Synthesis and Doping Process of the Catalysts}

The catalyst was synthesized in the form of powder as well as coated on the substrate. The synthesis of the catalyst and doping process was carried out by following a modified standard sol-gel method [42-43]. Preparation of the substrate was performed by an innovative method, while coating the thin film catalyst was done using the standard slurry coating procedure [27].

\section{Material and Chemicals}

- Titanium tetraisopropaoxide (97\%)

- Acitic acid (99.7\%)

- Silver nitrate $(99 \%)$

- Nitric acid

- Ethanol

- Deionized water

- Dental material

Equipment and Instrumentation

- Magnetic stirrer ( 0-1,400 rpm) for continuous mixing of the effluent

- Analytical balance (Sartorius, BL 210S)

- Oven (maximum rang $250^{\circ} \mathrm{C}$ )

- Furnace

Catalysts were synthesized using modified standard sol-gel methods [42-43].

\section{Method 1}

\section{Method 1a (M1A, Synthesis of $\mathrm{TiO}_{2}$ )}

$\mathrm{TiO}_{2}$ nano particles were prepared using the following modified sol-gel process (Fig. 2). A pre-determined amount of $\mathrm{Ti}(\mathrm{OBU})_{4}$ titanium tetra buta oxide was slowly added to the ethanol with constant stirring; nitric acid was then added to adjust the $\mathrm{pH}$ to 2 . Later on, deionized water
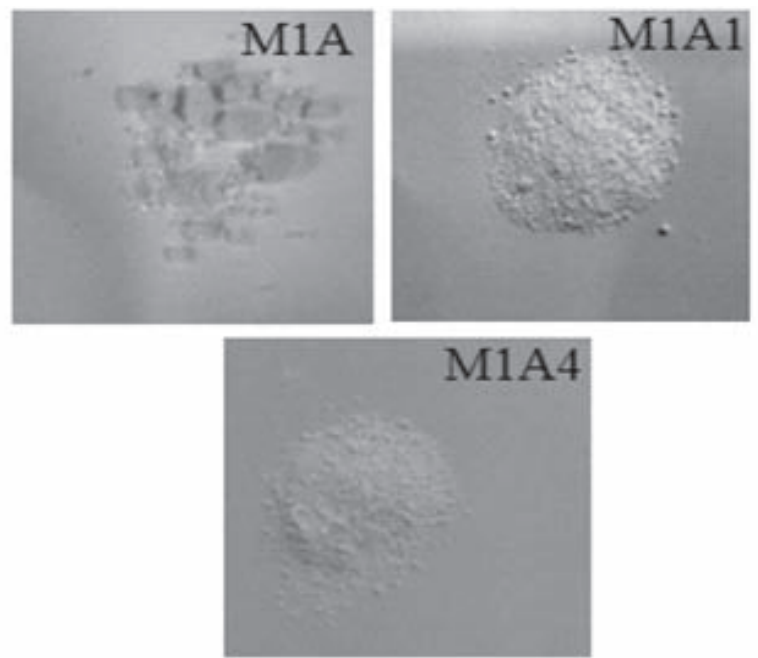

Fig. 2. Catalyst synthesized according to Method 1a before grinding (M1A) and after grinding (M1A1) before calcination; $\mathrm{M} 1 \mathrm{~A} 4$ is the form of catalyst calcinated at $550^{\circ} \mathrm{C}$.
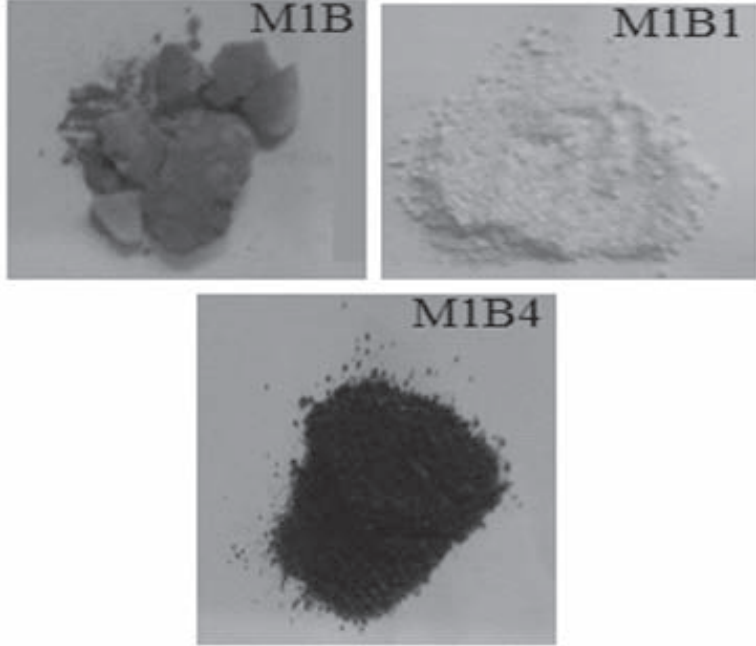

Fig. 3. Catalyst synthesized according to Method 1b: before grinding (M1B) and after grinding (M1B1) before calcination; $\mathrm{M} 1 \mathrm{~B} 4$ is the form of catalyst calcinated at $550^{\circ} \mathrm{C}$.

was added to the mixture with molar ratio controlled at ethanol:Ti(OBU)4:water $=20: 1: 2.5$. The mixture was stirred continuously for eight hrs and then kept at $30^{\circ} \mathrm{C}$ for several days until the gel formed. This gel was dried at $60-70^{\circ} \mathrm{C}$ in an oven in vacuum for two $\mathrm{hr}$ and then milled. The powdered form of $\mathrm{TiO}_{2}$ was calcinated at 550 for $1.5 \mathrm{hr}$.

Method $1 \mathrm{~b}\left(\mathrm{M} 1 \mathrm{~B}\right.$, synthesis and doping of $\mathrm{Ag}-\mathrm{TiO}_{2}$ )

$\mathrm{Ag}-\mathrm{TiO}_{2}$ nanoparticles were prepared by following the modified sol-gel process (Fig. 3). A predetermined amount of Ti(OBU) titanium tetra buta oxide was slowly added to the ethanol with constant stirring; nitric acid was then added to adjust the $\mathrm{pH}$ to 2 . Deionized water was then added to the mixture with the molar ratio controlled at ethanol:Ti(OBU)4: water $=20: 1: 2.5 . \mathrm{AgNO}_{3}$ was then added to the solution to produce a Ag:Ti molar ratio of 0.15 . The mixture was stirred continuously for eight hrs and then kept at $30^{\circ} \mathrm{C}$ for several days until a gel formed. The gel was dried at $60-70^{\circ} \mathrm{C}$ in an oven in vacuum for two hrs and then milled. $\mathrm{TiO}_{2}$ catalyst powder was calcinated at 550 for a half $\mathrm{hr}$ in furnace.

\section{Method 2}

Method 2a (M2A, Synthesis of $\mathrm{TiO}_{2}$ powder)

$\mathrm{TiO}_{2}$ nanoparticles were prepared by following Method 2a (Fig. 4). The sample was prepared by a modified SOL-Gel route. Titianium isopropaoxide $(25 \mathrm{ml})$ was added to acetic acid $(48 \mathrm{ml})$ with stirring. Water $(150 \mathrm{ml})$ was added to the mixture drop-wise with vigorous stirring. The titanium isopropaoxide, acetic acid, and water are in 1:10:100 molar ratio. The solution was stirred for eight hrs to get a clear transparent sol and allowed to dry at $30^{\circ} \mathrm{C}$ for several days, which was dried at $100^{\circ} \mathrm{C}$ for $15-30 \mathrm{~min}$, and later on calcined at $550^{\circ} \mathrm{C}$ in air for half an hr. 

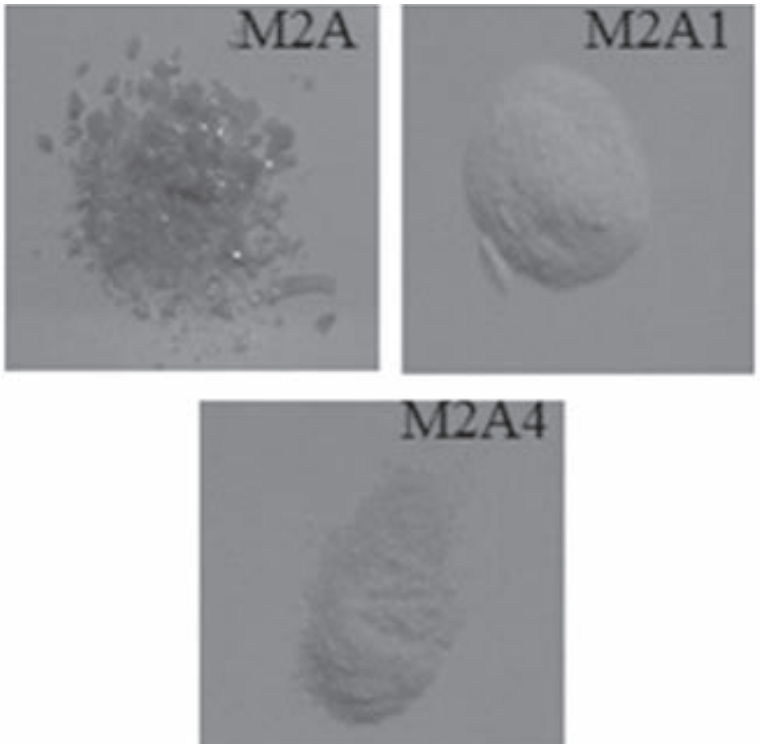

Fig. 4. Catalyst synthsized according to Method 2a: before grinding (M2A) and after grinding (M2A1) before calcination; $\mathrm{M} 2 \mathrm{~A} 4$ is the form of catalyst calcinated at $550^{\circ} \mathrm{C}$.

Method 2b (M2B, Synthesis and Doping of Ag- $\mathrm{TiO}_{2}$ powder)

Ag-TiO, nanoparticles were prepared by following Method 2a (Fig. 5). The sample was prepared by a modified sol-gel route. Tiitianiumisopropaoxide $(25 \mathrm{ml})$ was added to acetic acid $(48 \mathrm{ml})$ with continuous stirring. Water $(150 \mathrm{ml})$ was added to the mixture dropwise with vigorous stirring. To prepare silver-doped $\mathrm{TiO}_{2}$, silver nitrate $(3 \mathrm{~mol} \%$ ) was added along with adding water to the titanium iso-propaoxide mixture. The titanium isopropaoxide, acetic acid, and water were in molar ratio of 1:10:100. The solution was stirred for eight hrs to get a clear transparent sol and allowed to dry at $30^{\circ} \mathrm{C}$ for several days. Later on it was again dried at $100^{\circ} \mathrm{C}$ for $15-30 \mathrm{~min}$, which led to its calcination at 550 in air for $1.5 \mathrm{hrs}$.
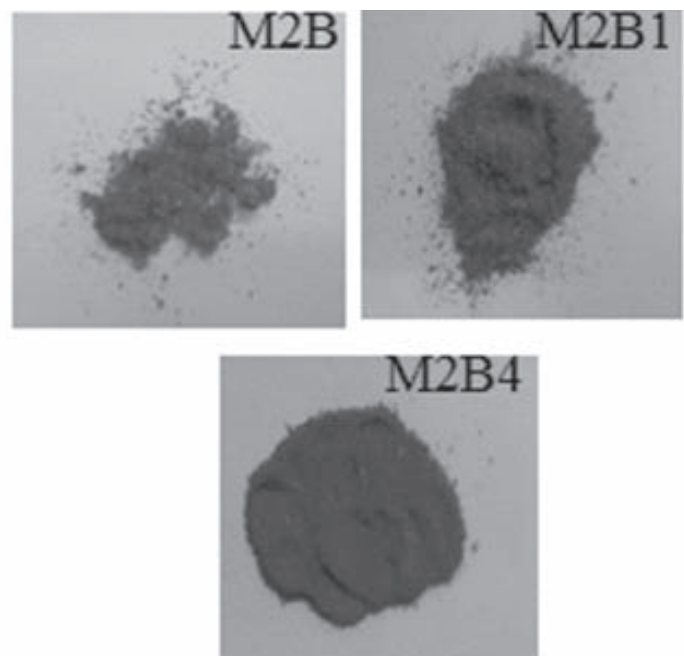

Fig. 5. Catalyst synthesized according to Method 2b: before grinding (M2B) and after grinding (M2B1) before calcination; $\mathrm{M} 2 \mathrm{~B} 4$ is the form of catalyst calcinated at $550^{\circ} \mathrm{C}$.

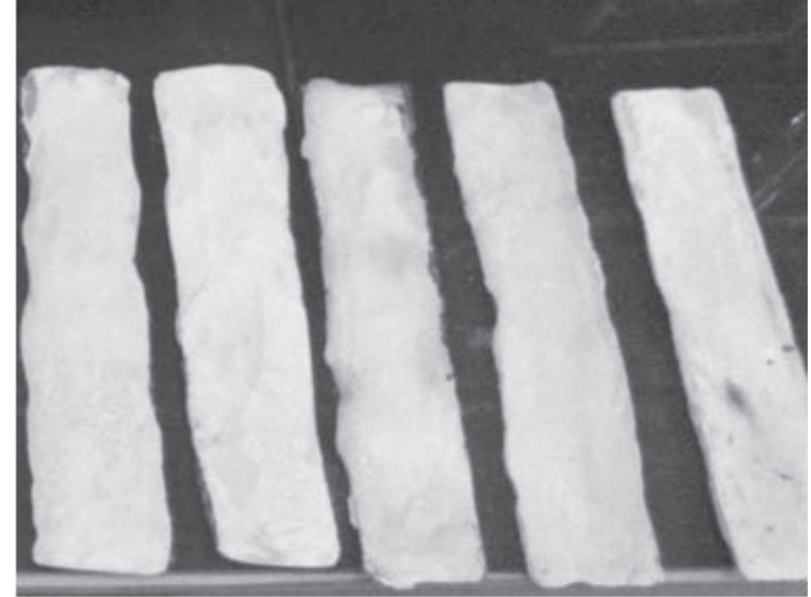

Fig. 6. Mesh-substrate (MS) coated (immobilized) by $\mathrm{TiO}_{2}$ catalyst.

\section{Mesh-Substrate Preparation and Coating (Immobilizing) Process}

\section{Preparation of the Mesh-Substrate}

Substate material is prepared by "dental material" (made in Germany), with water as a solvent. This suspended material was "slurry coated" on stainless steel mesh, air dried, and then put in an oven for one hr at $250^{\circ} \mathrm{C}$ (pre-heated). Further treatment was carried out at $750^{\circ} \mathrm{C}$ for $1 \mathrm{hr}$. The mesh was allowed to cool.

\section{Coating of the Catalyst on Mesh-Substrate}

Catalysts were prepared and coated according to the following processes:

\section{Preparation of $\mathrm{TiO}_{2}$-Coated Mesh-Substrate}

The sample was prepared by the modified sol-gel route mentioned in Method 2-a. The solution was stirred for eight hrs to get a clear transparent sol and allowed to set for $14 \mathrm{hrs}$. This prepared sol of $\mathrm{TiO}_{2}$ was slurry coated for four layers on the prepared mesh substrate and let dry at $30^{\circ} \mathrm{C}$ for one hr and then at $100^{\circ} \mathrm{C}$ for $30 \mathrm{~min}$. The catalystcoated mesh substrate was placed in a furnace for half an hour at $550^{\circ} \mathrm{C}$ and allowed to cool. This form of substrate was used in the next procedure (Fig. 6).

\section{Preparation of $\mathrm{Ag}$-TiO ${ }_{2}$-Doped-Coated (immobilized) Mesh-Substrate (MS)}

The sample was prepared by a modified sol-gel route as in Method 2-a. In addition (Fig. 7) to preparing silverdoped $\mathrm{TiO}_{2}$, silver nitrate $(3 \mathrm{~mol} \%$ ) was added along with water to the titanium iso-propaoxidemixture. The titanium isopropaoxide, acetic acid, and water were in molar ratio of 1:10:100. The solution was stirred for eight hrs to get a 


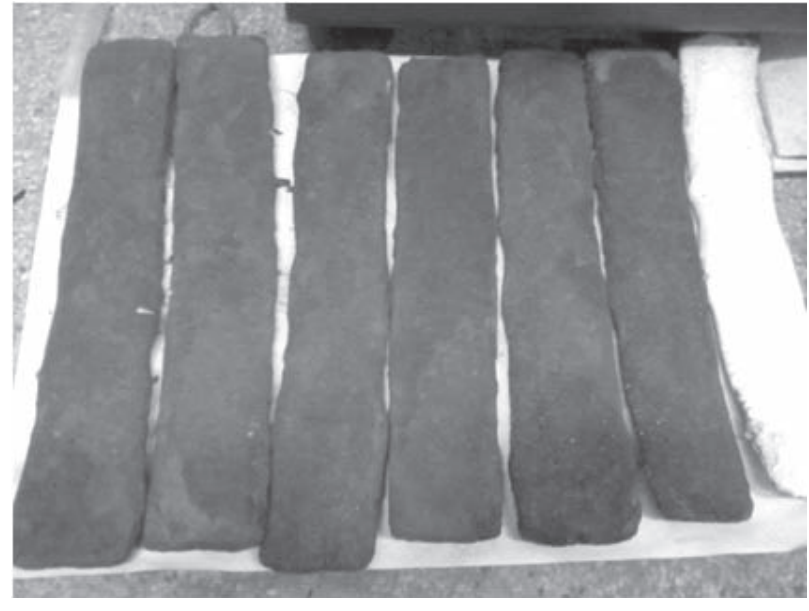

Fig. 7. Mesh substrate (MS) coated (immobilized) with $\mathrm{Ag}_{-} \mathrm{TiO}_{2}-$ doped catalyst.

clear transparent sol and, as mentioned, Method 2-b. The solution was stirred for eight hrs to get a clear transparent sol and then allowed to set for $14 \mathrm{hrs}$. After that this prepared sol of doped $\mathrm{Ag}-\mathrm{TiO}_{2}$ was slurry-coated for four layers on the prepared mesh-substrate (MS) and let dry at $30^{\circ} \mathrm{C}$ for one $\mathrm{hr}$ and then at $100^{\circ} \mathrm{C}$ for $30 \mathrm{~min}$. This slurry-coated mesh substrate was placed in the furnace for half an hour at $550^{\circ} \mathrm{C}$. After that the catalyst-coated mesh substrate (MS) was allowed to cool. This form of catalyst substrate was used in the photocatalytic oxidation process (Fig. 7)

\section{Preparation of Synthetic Textile Effluent}

\section{Chemicals and Materials}

Reactive dyes were used for dying and to produce synthetic and real textile effluent. Sodium sulphate $\left(\mathrm{Na}_{2} \mathrm{SO}_{4}\right)$ and sodium hydroxide $(\mathrm{NaOH})$ were used as exhaust and fixation agents, respectively. Sodium carbonate $\left(\mathrm{NaCO}_{3}\right)$ was also used as recommended by the dye manufacturer [44]. Reactive dyeing of cotton fabric also involves some additives, including salts, lubricants, and sequestering agents in order to aquire targeted dye quality. Ananti foaming agent (antimussol of clariant) was applied to suppress the foaming formation during the ozonation process.

Ferrous sulphatehepta hydrate $\left(\mathrm{FeSO}_{4} \cdot 7 \mathrm{H}_{2} \mathrm{O}\right), 0.25 \mathrm{~N}$ $\mathrm{K}_{2} \mathrm{Cr}_{2} \mathrm{O}_{7}$, ferrous ammonium sulfate, ferroin indicator, and borate buffer solution were used in this study. All the reagents were of analytical grade and obtained from BDH chemicals and MERCK. Ferrous sulphate was oven dried at $180^{\circ} \mathrm{C}$ for four hours. Acetic acid, $\mathrm{NaOH}, \mathrm{HCl}$, $\mathrm{H}_{2} \mathrm{SO}_{4}$, and $\mathrm{HNO}_{3}$ were prepared following the standard procedures for the adjustment of $\mathrm{pH}$ of the reaction and liquor $[42,43]$.

\section{Synthetic Effluent}

The Synthetic Effluent was prepared following the same composition recipe as for the standard real textile effluent.

\section{Dyes}

Dye stuff of major class (reactive remazol red RGB) was used at laboratory scale because of its common application in textile (cotton) dyeing due to such advantages as easy use, color brightness, and all-around fastness. The dye was supplied by Dystar, Germany - one of the world's main producers [44].

\section{Experimental Procedure}

Photocatalysis setup was used to treat synthetic textile effluent, and the process was optimized in terms of process conditions like temperature, $\mathrm{pH}$, catalyst dose, and radiation source. The textile effluent was characterized in terms of $\mathrm{pH}$, chemical oxygen demand (COD), and degree of decolourization (absorbance). Standard procedures given in "standard methods for the examination of water and wastewater" [45] were followed in order to evaluate the performance of the process during the treatment of textile effluent.

\section{Results and Discussion}

The photocatalytic degradation of textile dye effluent (remazol red RGB) through modified sol-gel synthesized mobilized, immobilized $\mathrm{TiO}_{2}$, and $\mathrm{TiO}_{2}$-Ag-doped titanium dioxide revealed the following results.

\section{Effect of $\mathrm{pH}$}

It is well known that the $\mathrm{pH}$ of a solution is one of the most important parameters in photocatalytic degradation of organic compounds [46-48]. This is attributed to the fact that $\mathrm{pH}$ not only determines chemical properties of the photocatalyst, but also influences adsorption behaviour of the pollutants [49-50]. It plays an important role in the photocatalytic reaction on the catalyst surfaces, where it affects the surface charge properties of the photocatalyst. It is well known that $\mathrm{pH}$ value has an influence on the kinetics of degradation of some organic compounds in photocatalytic processes $[51,3]$. Therefore, the effect of $\mathrm{pH}$ on degradation of textile dye effluent (Remazol Red RGB) was studied at varying $\mathrm{pH}$ ranges $(1,3,5,7,11)$. As shown in Figs 9 and 10, the most effective pH turned out to be 3. This may be ascribed to the fact that the $\mathrm{pH}$ value can influence the amount of hydroxyl radicals $(\mathrm{OH})$ formed. So the optimum $\mathrm{pH}$ of the solution found was $\mathrm{pH} 3$.

The results after treatment of Remazol Red RGB at different $\mathrm{pH}$ with $\mathrm{TiO}_{2}(0.5 \mathrm{~g}$ powder $), \mathrm{TiO}_{2}(1.5 \mathrm{~g}$ 


\section{Remazol Red RGB}

(Synthetic Textile Effluent)

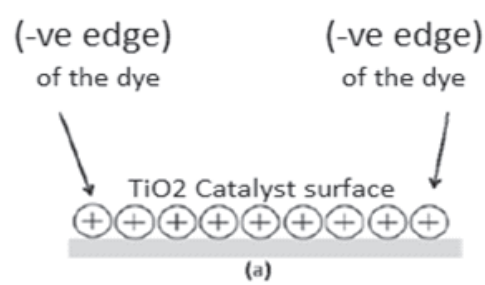

Remazol Red RGB

(Synthetic Textile Effluent)

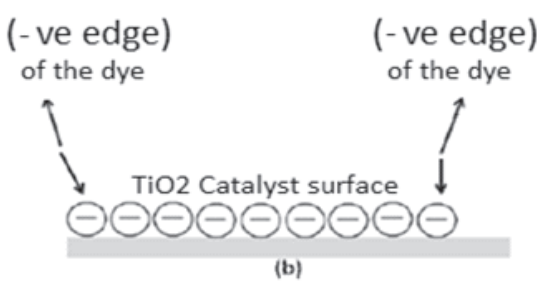

Fig. 8. Schematic interaction model of Remazol red RGB a) acid and b) basic sites.

powder), $\mathrm{TiO}_{2}$ (mesh), $\mathrm{Ag}-\mathrm{TiO}_{2}\left(0.5 \mathrm{~g}\right.$ powder), $\mathrm{Ag}-\mathrm{TiO}_{2}$ (1.5 g powder), and $\mathrm{Ag}^{-\mathrm{TiO}_{2}}$ (mesh) obtained from $\mathrm{COD}$ analysis are listed in Table 1 and Figs 9 and 10, which depict the color removal efficiency of Remazol Red RGB. Maximum decolorization of effluent was found to be at $\mathrm{pH} 3$ with different catalysts, i.e., $\mathrm{TiO}_{2}(0.5 \mathrm{~g}$ powder), $\mathrm{TiO}_{2}$ (1.5 g powder), $\mathrm{TiO}_{2}$ (mesh), Ag-TiO (0.5 g powder), $\mathrm{Ag}-\mathrm{TiO}_{2}\left(1.5 \mathrm{~g}\right.$ powder), and $\mathrm{Ag}-\mathrm{TiO}_{2}$ (mesh), whereas decolorization for effluent highest at pH 3 was 99.76\%, 99.8\%, 97.59\%, 99.64\%, 99.64\%, and $98.44 \%$, respectively, at UV (400W) radiation (Table 1).

Neutral $\mathrm{pH} \quad(\sim 7)$ was slightly favourable for decolorizing dye solutions. Interpreting $\mathrm{pH}$ effects on the efficiency of photodegradation is a difficult task because three possible reaction mechanisms can contribute to dye decolourization, mainly hydroxyl radical attack, direct oxidation by the positive hole, and direct reduction by electron in the conduction band. The importance of each depends on the substance nature and $\mathrm{pH}$ [52]. The point of zero charge (pzc) for $\mathrm{TiO}_{2}$ is 6.5-6.8. $\mathrm{TiO}_{2}$ surface is positively charged in acidic solutions and negatively charged in basic solutions (Fig. 8). The selected dyes manifested different adsorption behaviors on the surface of $\mathrm{TiO}_{2}$, and Remazol Red RGB was adsorbed on the surface of $\mathrm{TiO}_{2}[53,54]$. The hypothesis agrees with a reaction occurring on $\mathrm{TiO}_{2}$ surface and not in the solution, close to the surface.

The efficiencies of the photocatalytic process strongly depend on the $\mathrm{pH}$ of the reaction solution due to the amphoteric behaviour of the semi-conductor $\mathrm{TiO}_{2}$. The surface charge properties of $\mathrm{TiO}_{2}$ change when $\mathrm{pH}$ changes (Fig. 8). Moreover, the positive holes are considered the major oxidation species at low $\mathrm{pH}$, which react with hydroxide ions to form hydroxyl radicals, thus enhancing process efficiency. At increased $\mathrm{pH}$ there is a columbic repulsion between the negatively charged catalyst surface and the hydroxide anions that prevent the formation of $\mathrm{OH}^{\circ}$ and decrease photocatalytic degradation [54].

The presence and distribution of Ag species on the surface and inside the $\mathrm{TiO}_{2}$ film occurred in such a way that $\mathrm{TiO}_{2}$ was incorporated with metallic $\mathrm{Ag}$ in $\mathrm{Ag} / \mathrm{TiO}$ films. The distribution of $\mathrm{Ag}$ species is uniform and the amount of $\mathrm{Ag}$ species on the film surface increases with the increase in initial silver nitrate. Ag nanoparticles containing $\mathrm{Ag} / \mathrm{TiO}_{2}$ composite films were prepared by a sol-gel dip-coating method. These films exhibit excellent transmittance in the visible region [55], which is expected to lower resistance by incorporating metal nanoparticles in $\mathrm{TiO}_{2}$ film. Silver is a good conductor, which is why incorporating $\mathrm{Ag}$ nanoparticles with $\mathrm{TiO}_{2}$ matrix can be expected to form stable conducting paths inside the $\mathrm{TiO}_{2}$ matrix. Therefore, the resistance of $\mathrm{TiO}_{2}$ film can be lowered. In fact, $\mathrm{Ag} / \mathrm{TiO}_{2}$ composite films have been well studied in photocatalytic and nonlinear optical materials [56]. In these studies, the sol-gel process was the universal preparation method because its composition is perfectly controlled. In the present work, the sol-gel slurry-coating method was used to prepare the $\mathrm{Ag} / \mathrm{TiO}$ composite films at various calcination temperatures of $\mathrm{Ag}$ to investigate the effect of incorporating Ag nanoparticles on the electronic properties of $\mathrm{TiO}_{2}$ films [57].

Chin-Chaun Liu [58] stated that the positively charged $\mathrm{TiO}_{2}$ surface adsorbed more acid yellow 17 synthetic dye in acidic $\mathrm{pH}$, causing more degradation. Similarly, Bizani et al. investigated the degradation rate for two dye solutions in acidic, neutral, and alkaline $\mathrm{pH}$, and reported results in acidic conditions [59], while Reddy and Kotaiah [60] have observed a similar effect of $\mathrm{pH}$ on the degradation of simulated dyeing plant effluent. Hasnat et al. [61] examined Procion Red (an anionic dye) degradation under $\mathrm{pH}$ variation and found their best results at $\mathrm{pH} 3.22$.

\section{Effects of Different Catalysts}

We studied photo degradation of Remazol Red RGB synthetic textile effluent with different catalysts $\left(\mathrm{TiO}_{2}\right.$ $0.5 \mathrm{~g}, 1.5 \mathrm{~g}$, mesh and Ag-TiO2 0.5g, 1.5g, mesh) under optimum conditions (i.e., effluent initial COD $560 \mathrm{mg} / \mathrm{l}$ ), catalyst loading $(0.5 \mathrm{~g}, 1.5 \mathrm{~g}$, and mesh with four coatings), $\mathrm{pH} \mathrm{3,} \mathrm{synthetic} \mathrm{textile} \mathrm{effluent} \mathrm{volume} 1,000 \mathrm{ml}$, and radiation source of UV $(400 \mathrm{~W})$. Trends observed in the process of photocatalytic degradation of synthetic textile effluent with different types of catalysts were as follows (Figs 9 and 10):

- With $\mathrm{Ag}_{-} \mathrm{TiO}_{2}-\mathrm{Ag}-\mathrm{TiO}_{2}$ (mesh) (UV 400W) > Ag$\mathrm{TiO}_{2}(1.5)\left(\mathrm{UV} 400 \mathrm{~W}>\mathrm{Ag}-\mathrm{TiO}_{2}(0.5)(\mathrm{UV} 400 \mathrm{~W})\right.$

- With $\mathrm{TiO}_{2}-\mathrm{TiO}_{2}(0.5)(\mathrm{UV} 400 \mathrm{~W})>\mathrm{TiO}_{2}(1.5)(\mathrm{UV}$ $400 \mathrm{~W})>\mathrm{TiO}_{2}($ mesh $)(\mathrm{UV} 400 \mathrm{~W})>$

...whereas if we report the collective catalyst trend observed, it was $\mathrm{Ag}-\mathrm{TiO}_{2}$ (mesh) $(\mathrm{UV} 400 \mathrm{~W}) \sim \mathrm{TiO}_{2}(0.5)$ 
Table 1. COD percentage removal and ABS percentage removal results with different types of catalysts and different $\mathrm{pH}$ values under $\mathrm{UV}(400 \mathrm{~W})$ radiation.

\begin{tabular}{|c|c|c|c|c|c|c|c|c|c|c|c|}
\hline \multirow{3}{*}{$\begin{array}{l}\text { Sr. } \\
\text { No. }\end{array}$} & \multirow{3}{*}{$\begin{array}{l}\text { Types of } \\
\text { Catalysts }\end{array}$} & \multicolumn{10}{|c|}{ Under UV (400 W) Radiation } \\
\hline & & \multicolumn{2}{|c|}{$\mathrm{pH} 1$} & \multicolumn{2}{|c|}{ pH 3} & \multicolumn{2}{|c|}{$\mathrm{pH} 5$} & \multicolumn{2}{|c|}{$\mathrm{pH} 7$} & \multicolumn{2}{|c|}{ pH11 } \\
\hline & & $\begin{array}{l}\text { COD \% } \\
\text { Removal }\end{array}$ & $\begin{array}{c}\text { ABS \% } \\
\text { Removal }\end{array}$ & $\begin{array}{l}\text { COD \% } \\
\text { Removal }\end{array}$ & $\begin{array}{c}\text { ABS \% } \\
\text { Removal }\end{array}$ & $\begin{array}{c}\text { COD \% } \\
\text { Removal }\end{array}$ & $\begin{array}{c}\text { ABS \% } \\
\text { Removal }\end{array}$ & $\begin{array}{c}\text { COD \% } \\
\text { Removal }\end{array}$ & $\begin{array}{c}\text { ABS \% } \\
\text { Removal }\end{array}$ & $\begin{array}{l}\text { COD \% } \\
\text { Removal }\end{array}$ & $\begin{array}{c}\text { ABS \% } \\
\text { Removal }\end{array}$ \\
\hline 1 & $\mathrm{TiO}_{2}(0.5)$ & 88.58 & 99.34 & 94.29 & 99.76 & 85.72 & 97.35 & 76.43 & 96.21 & 68.58 & 87.4 \\
\hline 2 & $\mathrm{TiO}_{2}(1.5)$ & 85.72 & 99.4 & 92.17 & 99.82 & 82.86 & 99.28 & 65.72 & 97.59 & 54.29 & 97.53 \\
\hline 3 & $\mathrm{TiO}_{2}(\mathrm{Mesh})$ & 82.86 & 96.93 & 91.43 & 97.59 & 71.43 & 96.75 & 68.51 & 95.42 & 71.43 & 95 \\
\hline 4 & $\mathrm{Ag}-\mathrm{TiO}_{2}(0.5)$ & 82.86 & 98.98 & 88.58 & 99.64 & 80 & 97.35 & 65.72 & 97.05 & 71.43 & 96.75 \\
\hline 5 & $\mathrm{Ag}-\mathrm{TiO}_{2}(1.5)$ & 88.58 & 99.4 & 91.43 & 99.64 & 77.15 & 99.4 & 74.29 & 97.59 & 68.58 & 97.53 \\
\hline 6 & $\mathrm{Ag}-\mathrm{TiO}_{2}(\mathrm{Mesh})$ & 91.43 & 97.53 & 94.29 & 98.44 & 66 & 91.8 & 51.43 & 88.36 & 31.43 & 85.53 \\
\hline
\end{tabular}

$(\mathrm{UV} 400 \mathrm{~W})>\mathrm{TiO}_{2}(1.5)(\mathrm{UV} 400 \mathrm{~W})>\mathrm{Ag}-\mathrm{TiO}_{2}(1.5)$ $(\mathrm{UV} 400 \mathrm{~W}) \sim \mathrm{TiO}_{2}\left(\right.$ mesh) $(\mathrm{UV} 400 \mathrm{~W})>\operatorname{Ag}-\mathrm{TiO}_{2}(0.5)$ (UV 400W)

Maximum degradation took place when $\mathrm{Ag}-\mathrm{TiO}_{2}$ (mesh) (UV 400W) is used as compared to $\mathrm{TiO}_{2}$, because
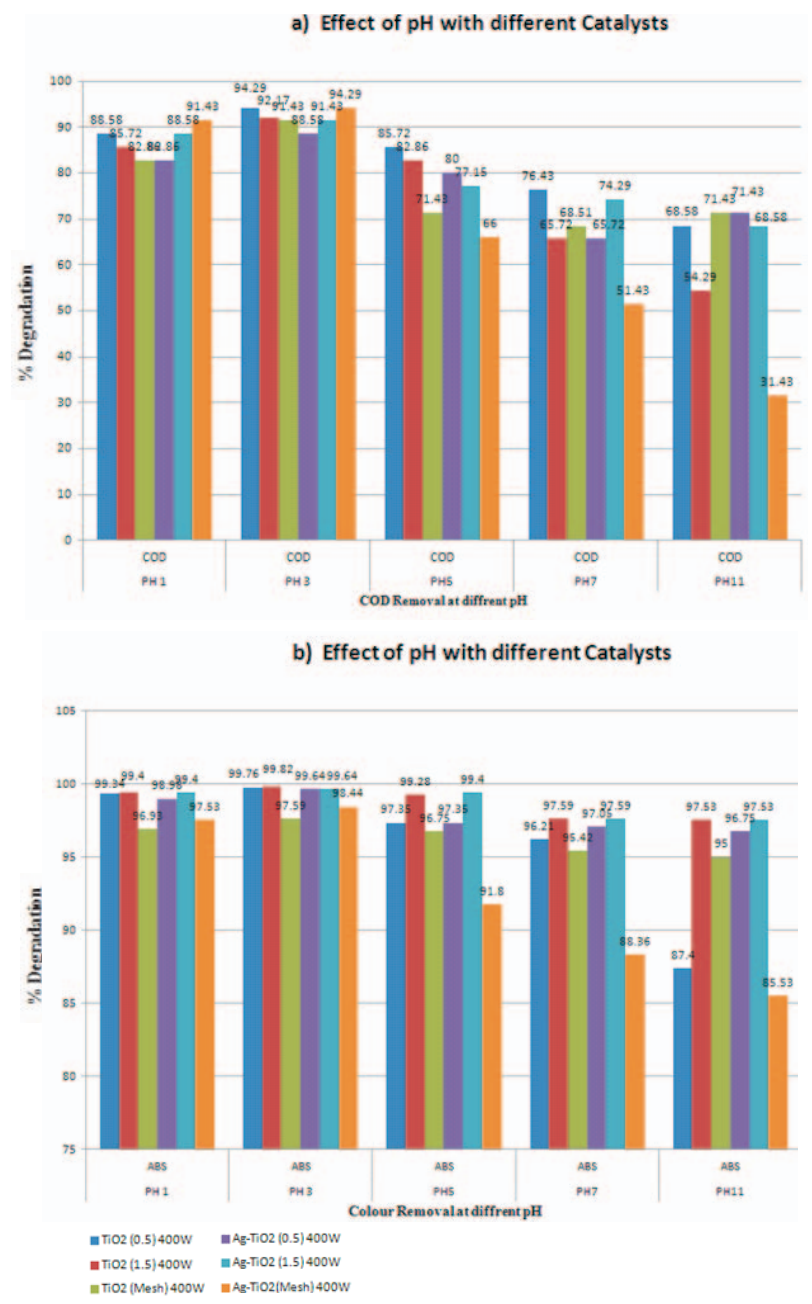

Fig. 9. Effects of $\mathrm{pH}$ on a) COD percentage removal values and b) ABS percentage removal values with different catalysts using UV (400 Watt) radiation. of the slow combination of electron hole pair and large surface area of the mesh $[35,19]$. When titanium dioxide $\left(\mathrm{TiO}_{2}\right)$ is radiated with intensity of band gap energy (3.2Ev), it generates electrons of band (eCB)- and hoes in valance band $(\mathrm{hVB})+$. These charges can recombine, or the holes can be scavenged by oxidizing species (for
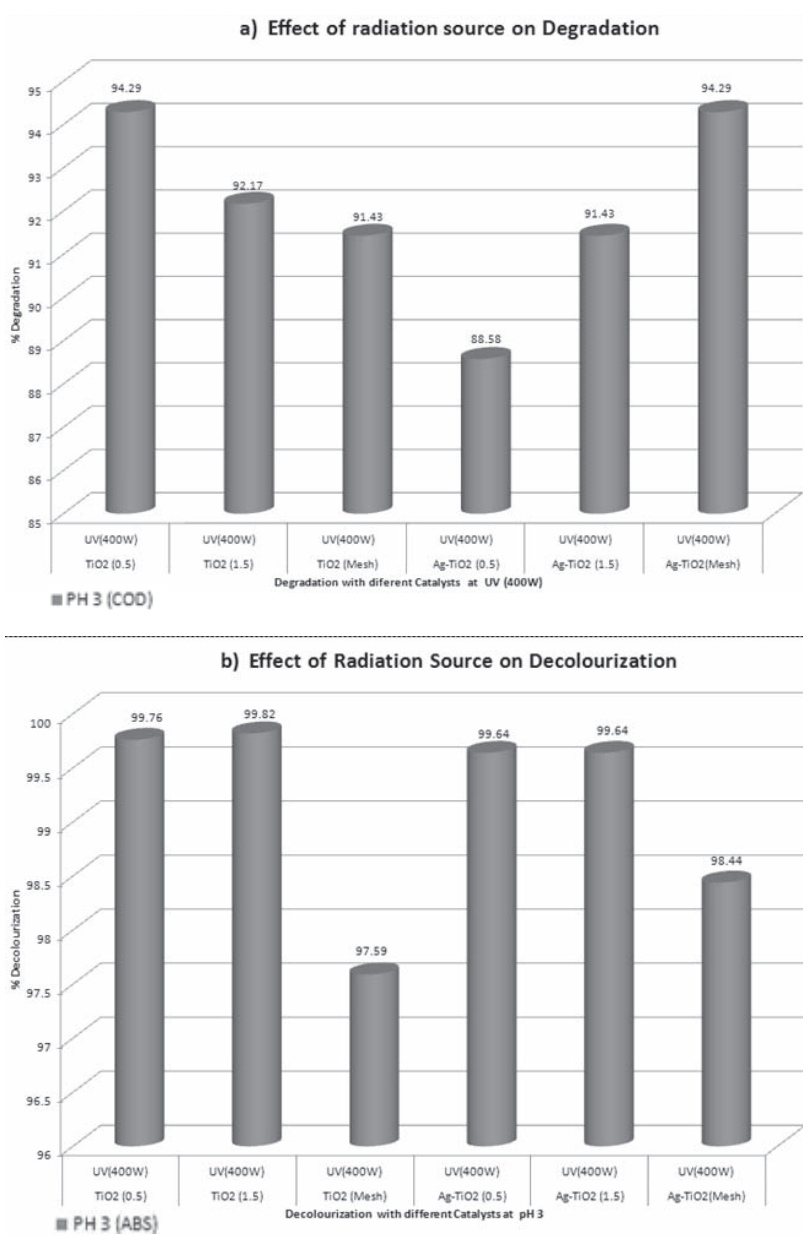

Fig. 10. Effects of radiation sources on decolorization of effluent when treated with different types of catalysts under UV (400 Watt) radiation. 
example $\mathrm{H}_{2} \mathrm{O}, \mathrm{OH}-$ ), and electron by reducible spieces. The following reaction scheme illustrates the mechanism [62-63].

$$
\begin{gathered}
\mathrm{TiO}_{2}+\mathrm{h} v \rightarrow \mathrm{e}^{-}+\mathrm{p}^{+} \\
\mathrm{e}^{-}+\mathrm{O}_{2} \rightarrow \mathrm{O}^{-2} \\
\mathrm{p}^{+}+\mathrm{Pol} \rightarrow \mathrm{CO}_{2} \\
\mathrm{p}^{+}+\mathrm{H}_{2} \mathrm{O} \rightarrow \bullet \mathrm{OH}+\mathrm{H}^{+} \\
\mathrm{OH}+\mathrm{Pol} \rightarrow \mathrm{CO}_{2}
\end{gathered}
$$

\section{Working Principle of Ag-Doped $\mathrm{TiO}_{2}$ Catalyst}

In the Ag-doped $\mathrm{TiO}_{2}$ catalyst, electrons in the valence band of $\mathrm{TiO}_{2}$ are excited to the conduction band, leaving holes in its valence band.

$$
\begin{gathered}
\mathrm{TiO}_{2}+\mathrm{h} v \rightarrow \mathrm{e}_{(\mathrm{CB}-\mathrm{TiO} 2)}^{-}+\mathrm{h}^{+}{ }_{(\mathrm{VB})} \\
\mathrm{Ag}^{0}+\mathrm{h} v \mathrm{Ag}^{+} \rightarrow+\mathrm{e}_{(\mathrm{CB}-\mathrm{Ag})}^{-} \\
\mathrm{e}_{(\mathrm{CB}-\mathrm{Ag})}^{-}+\mathrm{O}_{2 \text { (ads) }} \rightarrow \mathrm{O}_{2}^{\bullet-}{ }_{\text {(reactive spieces) }}
\end{gathered}
$$

Eqs 7 and 8 can be combined in the form of equation 9:

$$
\mathrm{Ag}^{0}+\mathrm{O}_{2} \rightarrow \mathrm{Ag}^{+}+\mathrm{O}_{2}^{\bullet-} \text { (reactive spieces) }
$$

...whereas $\mathrm{Ag}^{+}$ande $^{-}{ }_{(\mathrm{CB}-\mathrm{TiO} 2)}$ formed in Eqs. 6, 7, and 8 combine to form $\mathrm{Ag}^{0}$ (Eq. 10):

$$
\mathrm{Ag}^{+}+\mathrm{e}_{\left(\mathrm{CB}-\mathrm{TiO}_{2}\right)}^{-} \rightarrow \mathrm{Ag}^{0}
$$

At the same time, electrons of Ag nanoparticles are excited when irradiated with the light of their excitation wavelength (Eq 7) and the electrons attack the adsorbed oxygen and $\mathrm{O}_{2}{ }^{-}-$is formed (Eq. 8). Combining equations 7 and $8, \mathrm{Ag}$ nanoparticles transform into colorless $\mathrm{Ag}^{+}$ions (Eq. 9) [64-65]. The $\mathrm{Ag}^{+}$ions are reduced by the excited electrons of $\mathrm{TiO}_{2}$, and $\mathrm{Ag}$ nanoparticles are formed (Eqs 9, 10). This metal and co-metal mechanism has been reported to give improved photocatalytic activity [66].

The hydroxyl radical (like $\mathrm{OH}^{\circ}$ ) is a highly reactive oxidizing reagent and proved to be very effective in degrading many organic contaminants [67-68]. However, the limitation is to separate nanoparticles of $\mathrm{TiO}_{2}$ from the suspension after treatment. On the other hand, immobilizing catalyst onto a suitable solid inert material is a better option [69-70].

\section{Effects of Catalyst Dose}

After optimizing $\mathrm{pH}$, the catalyst dose is another important parameter that strongly influences the degradation of effluent. $\mathrm{TiO}_{2}$ ( $0.5 \mathrm{~g}$ powder $), \mathrm{TiO}_{2}(1.5 \mathrm{~g}$ powder $), \mathrm{TiO}_{2}$ (mesh), $\mathrm{Ag}-\mathrm{TiO}_{2}\left(0.5 \mathrm{~g}\right.$ powder), $\mathrm{Ag}-\mathrm{TiO}_{2}$ (1.5 g powder), and $\mathrm{Ag}-\mathrm{TiO}_{2}$ (mesh) catalysts were used in this study. In order to determine the optimal amount of catalyst concentration, a series of experiments were carried out using different concentrations of catalysts at optimized $\mathrm{pH}$ of 3.0 with $560 \mathrm{mg} / 1$ initial COD of synthetic textile effluent (Figs 9 and 10). The graph depicts that as the concentration of catalyst increases from $\mathrm{Ag}_{-} \mathrm{TiO}_{2}(0.5 \mathrm{~g}$ powder $)$, $\mathrm{Ag}-\mathrm{TiO}_{2}$ (1.5 g powder) and $\mathrm{Ag}-\mathrm{TiO}_{2}$ (mesh), the percentage degradation increases to $88.58 \%, 91.43 \%$, and $94.29 \%$ for UV (400W) radiation, respectively. The quantity and form of the photocatalyst is the most essential parameter that affects the rate of photocatalytic degradation. The degradation rate increased with increases in catalyst concentration because of the availability of more catalyst surface area for absorption of photons and interaction of molecules of reaction with the catalyst. The result is that the number of holes and hydroxyl radicals and super oxide radicals increased [71] (Table 1 and Figs 9-10).

The rate of degradation increases with increased catalyst amounts due to the availability of more catalyst surface area for absorption of quanta and interaction of molecules of reaction mixture with catalyst, but access leads to a decrease in the rate. Hence, further addition of catalysts does not lead to enhancing the degradation rate and it remains constant [72-73].

Results indicate that $\mathrm{TiO}_{2}(0.5 \mathrm{~g}$ powder $), \mathrm{TiO}_{2}$ ( 1.5 g powder) percentage degradation decreased to $94.29 \%$ and $92.17 \%$ with the UV $(400 \mathrm{~W})$ radiation, respectively, whereas for treatment with $\mathrm{TiO}_{2}$ (mesh four layers of coating) the percentage of degradation with UV $(400 \mathrm{~W})$ was $91.43 \%$ (Figs 9-10). So the maximum degradation rate has been observed with the catalyst $\mathrm{Ag}-\mathrm{TiO}_{2}$ (mesh four layers of coating) with UV (400 W) as $94.29 \%$, as well as $94.29 \%$ with $\mathrm{TiO}_{2}(0.5 \mathrm{~g}$ powder $)$ as catalyst. Silva et al. [74] reported that the degree of decolorization increases with the increasing amount of catalyst concentration up to a certain limit, and beyond that after further increase in catalyst dose decolorization decreased. Faisal et al. [75] documented the effect of catalyst dose on two dyes, acridine orange and ethidium bromide, and observed that the degradation rate for the decomposition of both dyes in the presence of $\mathrm{TiO}_{2}$ Degussa P25 increases with the increase in catalyst concentration, and a further increase in catalyst concentration leads to a decrease in degradation rate.

Table 2. Descriptive analysis: values of mean(M) and standard deviation (SD) of initial $\mathrm{pH}$ and types of catalysts.

\begin{tabular}{|c|c|c|}
\hline Parameters & $\begin{array}{c}\text { Mean }(\mathrm{M}) \\
\mathrm{n}=30\end{array}$ & $\begin{array}{c}\text { Standard Deviation } \\
(\mathrm{SD}) \mathrm{n}=60\end{array}$ \\
\hline Initial $\mathrm{pH}$ & 3 & 1.438 \\
\hline Types of Catalysts & 3.5 & 1.737 \\
\hline
\end{tabular}


Table 3. One-way ANOVA results of mean COD percentage removal and mean ABS percentage removal with respect to the initial $\mathrm{pH}$ factor.

\begin{tabular}{|c|c|c|c|c|c|c|c|}
\hline \multirow{2}{*}{ Variables } & \multicolumn{6}{|c|}{ Initial pH } & \multirow[b]{2}{*}{ Decision } \\
\hline & & $\begin{array}{l}\text { Sum of } \\
\text { Squares }\end{array}$ & Df & $\begin{array}{l}\text { Mean } \\
\text { Square }\end{array}$ & $\mathrm{F}$ & $\begin{array}{c}\text { Sig. } \\
(p<0.05)\end{array}$ & \\
\hline \multirow{3}{*}{$\begin{array}{c}\text { Mean COD } \\
\text { percentage Removal }\end{array}$} & Between Groups & 4123.270 & 4 & 1030.817 & \multirow{3}{*}{12.884} & \multirow{3}{*}{0.000} & \multirow{3}{*}{$\begin{array}{c}\text { Significant mean } \\
\text { difference }\end{array}$} \\
\hline & Within Groups & 2000.208 & 25 & 80.008 & & & \\
\hline & Total & 395.155 & 29 & & & & \\
\hline \multirow{3}{*}{$\begin{array}{c}\text { Mean ABS percentage } \\
\text { Removal }\end{array}$} & Between Groups & 138.417 & 4 & 34.604 & \multirow{3}{*}{3.370} & \multirow{3}{*}{0.025} & \multirow{3}{*}{$\begin{array}{l}\text { Significant mean } \\
\text { difference }\end{array}$} \\
\hline & Within Groups & 256.738 & 25 & 10.270 & & & \\
\hline & Total & 395.155 & 29 & & & & \\
\hline
\end{tabular}

Table 4. The results of the Tukey post hoc tests (multiple comperision) dependent variable: COD percentage removal and ABS percentage removal (Tukey HSD).

\begin{tabular}{|c|c|c|}
\hline \multirow{4}{*}{$\begin{array}{c}\text { COD } \\
\text { percentage } \\
\text { removal }\end{array}$} & $\begin{array}{c}\text { Significance Mean Difference } \\
\text { Between the Groups }\end{array}$ & $p<0.05$ \\
\cline { 2 - 3 } & $\mathrm{pH}$ 1 VS pH7 & 0.007 \\
\cline { 2 - 3 } & $\mathrm{pH}$ 1 VS pH 11 & 0.000 \\
\cline { 2 - 3 } & $\mathrm{pH} 3 \mathrm{VS} \mathrm{pH} \mathrm{5}$ & 0.049 \\
\cline { 2 - 3 } & $\mathrm{pH} 3 \mathrm{VS} \mathrm{pH} 7$ & 0.000 \\
\hline $\begin{array}{c}\text { ABS } \\
\text { percentage } \\
\text { removal }\end{array}$ & $\mathrm{pH} 5 \mathrm{VS} \mathrm{pH} \mathrm{11}$ & 0.000 \\
\hline
\end{tabular}

\section{Statistical Analysis}

The data was analyzed with SPSS V15 using mean, standard deviation, and analysis of variance (ANOVA) [54]. The statistical significance of the main effects and interactions of the factors on the two results were evaluated by ANOVA based on the pure error mean square estimated from the variance of the response values.

\section{Descriptive Analysis}

According to the descriptive analysis the mean value for the parameter "Intial $\mathrm{pH}$ " is $\mathrm{M}=3$ and $\mathrm{SD}=1.438$, and for the parameter "Types of catalysts" $\mathrm{M}=3.5$ and $\mathrm{SD}=1.737$

The values of "initial $\mathrm{pH}$ " $\mathrm{M}=3$ means that the results of the treatment are in favor of $\mathrm{pH} 3$, as well as $\mathrm{SD}=1.438$, which is near to 1 , indicating that the overall treatment result values at $\mathrm{pH} 3$ are not scattered [76]. Similarly, the values of "Types of Catalyst" $\mathrm{M}=3.5$ indicate that better treatment results have been shown by the catalyst category of $\mathrm{Ag}-\mathrm{TiO}_{2} \mathrm{SD}=1.737$, which being near 1 indicates that the vales are not scattered (Table 2).

\section{One-Way ANOVA}

Values of Chemical Oxygen demand (COD) obtained at different $\mathrm{pH}(1,3,5,7$, and 11) for treatment of Remazol Red RGB synthetic effluent were compared through oneway ANOVA tests (Statistics 15; SPSS Inc. Package) (Table 3). According to the results, there was a significant effect of "initial $\mathrm{pH}$ " $(p<0.05)$ as $\mathrm{p}$-value is 0.000 and $\mathrm{F}=12.884$ for COD percentage removal, and $\mathrm{p}$-value is 0.025 and $\mathrm{F}=3.370$ for ABS percentage removal, which is less than the significance level of 0.05 . These values indicate that there is a significant mean difference in the COD percentage removal and ABS percentage removal values when considering the parameter of initial $\mathrm{pH}$ $(1,3,5,7$, and 11). Thus, post hoc testing revels that the significant difference found in the results of treatment at $\mathrm{pH} 1(p<0.05), \mathrm{pH} 3(p<0.05)$ and $\mathrm{pH} 5(\mathrm{p}>0.05)$ showed better COD removal percentage than $\mathrm{pH} 7(p<0.05)$ and $\mathrm{pH} 11(p<0.05)$ (Table 4). Post Hoc testing also revealed that the significance difference found in ABS percentage removal treatment obtained better results at $\mathrm{pH} 3(p<0.05)$ and $\mathrm{pH} 11(p<0.05)$ (Tables 3-4).

\section{Conclusion}

The Ag- $\mathrm{TiO}_{2}$-doped technique was used for UV photo catalyst. This technique successfully improves the degradation rate of the synthetic effluent. The photocatalytic degradation efficiency increased when the catalyst was doped with $\mathrm{Ag}$. $\mathrm{Ag}-\mathrm{TiO}_{2}$ proved to be more efficient in the UV 400W light, moreover, among all the catalyst types (mobilized and immobilized), the immobilized $\mathrm{Ag}-\mathrm{TiO}_{2}$ (mesh) at optimum $\mathrm{pH} 3$ at initial COD value of $560 \mathrm{mg} / \mathrm{l}$ performed the best. This is a vital step toward the cost-effective approach of photocatalysis, as these meshes can be reused and the cost of filtration of effluent is saved [58].

We conclude that this process can be used as an efficient and environmentally friendly technique for effluent treatment of the textile industry. Development of this technology is important and beneficial in Pakistan because sunlight is abundant in this region. 


\section{References}

1. BISSCHOPS I., SPANJERS H. Literature review on textile wastewater characterisation. Environ. Technol. 24, 1399, 2003.

2. IMTIAZUDDIN, S.M., MUMTAZ, M., MALLICK, K. A. Pollutants of Wastewater Characteristics in Textile Industries. J. Basic. Appl. Sci. 8, 554, 2012.

3. REGULSKA E., BRUS D.M., KARPINSKA J. Photocatalytic decolourization of direct yellow 9 on titanium and zinc oxides. Int. J. Photoenergy. 1, 2013.

4. AZBAR N., YONAR T., KESTIOGLU K. Comparison of various advanced oxidation processes and chemical treatment methods for COD and colour removal from a polyester and acetate fiber dyeing effluent. Chemosphere. 55 (1), 35, 2004

5. YUSUFF R.O., SONIBARE J.A. Characterization of textile industries effluents in kaduna, Nigeria and pollution implications. Global Nest: the Int. J. 6 (3), 212, 2004.

6. HUSSEIN F.H. Effect of photocatalytic treatments on physical and biological properties of textile dyeing wastewater. Asian J. Chem. 25 (16), 9387, 2013.

7. COMNINELLIS C., KAPALKAA., MALATOS., PARSONS S.A., POULIOS I., MANTZAVINOS D. Perspective Advanced oxidation processes for water treatment: advances and trends for R and D. J. Chem. Technol. Biotechnol. 83, 769, 2008.

8. HANIF A.M., NADEEM R., ZAFAR N.M., BHATTI N.H., NWAZ R. Physico-chemical treatment of textile wastewater using natural coagulant cassia fistula (golden shower) pod biomass. J. Chem. Soc. Pak. 30 (3), 385, 2008.

9. SEO J.S., KEUM Y.S. AND LI Q.X. Bacterial degradation of aromatic compounds. Int. J. Environ. Res. Public health. 6, 278, 2009.

10. HONADE S., SHRIVASTAVA N. Oxidative processes in effluent treatment. J. Textile Assoc. 71, 5, 2010.

11. OLLER I., MALATO S., SANCHEZ-PEREZ J.A. Combination of advance oxidation processes and biological treatment of wastewater decontamination-A review. Sci. Total Environ. 409 (20), 4141, 2011.

12. KAUR H., SHARMA G. Removal of Dyes from Textile Industry Effluent: A Review. SSRG- IJHSS. 59, 2015.

13. NAWAZ S.M., AHSAN M. Comparison of physicochemical, advanced oxidation and biological techniques for the textile wastewater treatment. Alexandria Eng. J. 53 (3), 717, 2014.

14. STASINAKIS A.S., Use of selected advanced oxidation processes (AOPs) for wastewater treatment - a mini review. Global Nest: the Int. J. 10 (3), 376, 2008.

15. TOUAT A., HAMMEDI T., NAJJAR W., KSIBI Z., SAYADI S. Photocatalytic degradation of textile wastewater in presence of hydrogen peroxide: Effect of cerium doping titania. J. Ind. Eng. Chem. In press. 2015.

16. MOHAJERANI M., MEHRVAR M., EIN-MOZAFFARI F. An overview of the integration of advanced oxidation technologies and other processes for water and wastewater treatment. Int. J. Eng. 3 (2), 120, 2009.

17. KLAVARIOTI M., MANTZAVINOS D., KASSINOS D. Removal of residual pharmaceuticals from aqueous systems by advanced oxidation processes. Environ. Int. 35, 402, 2009.

18. SIMA J., HASAL P. Photocatalytic degradation of textile dyes in $\mathrm{aTiO}_{2}$ UVV system. Chem. Eng. Trans. 32, 2013

19. CHEN F., ZOU W., QU W., ZHANG J. Photocatalytic performance of a visible light $\mathrm{TiO}_{2}$ photocatalyst prepared by a surface chemical modification process. Catal Commun. 10, 1510, 2009

20. GRZECHULSKA-DAMSZEL J., TOMASZEWSKA M., MORAWSK A.W. Integration of photocatalysis with membrane processes for purification of water contaminated with organic dyes. Desalination, 241, 118, 2009.

21. RAUF M.A., BUKALLAH S.B., HAMMADI A., SOLIMAN A., HAMMADI F. The effect of operational parameters on the photoinduced decoloration of dyes using a hybrid catalyst $\mathrm{V}_{2} \mathrm{O}_{5} / \mathrm{TiO}_{2}$. Chem. Eng. J. 129, 167, 2007.

22. SONG L., ZENG X., ZHANG X. Application of poly (fluorene-co-bithiophene) as a novel sensitizer for $\mathrm{TiO}_{2}$ in the photodegradation of phenol under irradiation of $\mathrm{GaN}$ LED cluster. React. Kinet. Mech. Cat. 102 (2), 295, 2011.

23. AHMED S., RASUL M. G., MARTENS W. N., BROWN R. HASHIB M. A. Advances in heterogeneous photocatalytic degradation of phenols and dyes in wastewater: a review. Water Air Soil Poll. 215, 3, 2011.

24. MOHAMED A.E.R., ROHANI S. Modified $\mathrm{TiO}_{2}$ nanotube arrays (TNTAs): progressive strategies towards visible light responsive photoanode, a review. Energ. Environ. Sci. 4 (4), 1065,2011

25. DIEBOLD U. Photocatalysts: Closing the gap. Journal name: Nat. Chem. 3, 271, 2011.

26. ZALESKA A. Doped-TiO : A Review. Recent Pat. Eng. 2 , $157,2008$.

27. WANG Q., JIANG Z., WANG Y., CHEN D., YANG D. Photocatalytic properties of porous C-doped $\mathrm{TiO}_{2}$ and $\mathrm{Ag} / \mathrm{C}$-doped $\mathrm{TiO}_{2}$ nanomaterials by eggshell membrane templating. J. Nanopart. Res. 11, 375, 2009.

28. SHAO R., SUN L., TANG L., CHEN Z. Preparation and characterization of magnetic core-shell $\mathrm{ZnFe}_{2} \mathrm{O}_{4}$ with $\mathrm{ZnO}$ nanoparticles and their application for the photodegradation of methylene blue. Chem. Eng. J. 217, 185, 2013.

29. SHARMA K., SINGH G., SINGH G., KUMAR M., BHALLA V. Silver nanoparticles: facile synthesis and their catalytic application for the degradation of dyes. RSC Adv. 5, 25781, 2015.

30. VANAJA M., PAULKUMAR K., BABURAJA M., RAJESHKUMAR S., GNANAJOBITHAG., MALARKODI C., SIVAKAVINESAN M., ANNADURAI G. Degradation of methylene blue using biologically synthesized silver nanoparticles. Bioinorg. Chem. Appl. Article ID 742346, 2014.

31. ABHANG R.M., KUMAR D., TARALKAR S.V. Design of photocatalytic reactor for degradation of phenol in wastewater. Int. J. Chem. Eng. Appl. 2 (5), 337, 2011.

32. MCCULLAGH C., SKILLEN N., ADAMS M. ROBERTSON P.K.J. Photocatalytic reactors for environmental remediation: a review. J. Chem. Technol. Biotechnol. 86 (8), 1002, 2011.

33. MOTEGH M., OMMEN J.R., APPEL PETER W.M.T. Scale-up study of a multiphase photocatalytic reactor degradation of cyanide in water over $\mathrm{TiO}_{2}$. Environ. Sci. Technol. 48 (3), 1574, 2014.

34. BIRNIE M., RIFFAT S., GILLOTT M. Photocatalytic reactors: design for effective air purification. Int. J. LowCarbon Tech. 1 (1), 47, 2006.

35. CALIMAN A.F., BALASANIAN I. Reactors for application in heterogeneous photocatalysis. Environ. Eng. Manag. J. 4 (3), 371, 2005.

36. SERRANO B., ORTIZ A., MOREIRA J., LASA H.I. Photocatalytic thermodynamic efficiency factors: practical limits in photocatalytic reactors. Ind. Eng. Chem. Res. 49 (15), 6824, 2010 
37. JEON J.H., KIM S.D., LIM T.H., LEE D.H. Degradation of trichloroethylene by photocatalysis in an internally circulating slurry bubble column reactor. Chemosphere. 60, $1162,2005$.

38. NOISOMRAN R., KHONGTHON W., SANGVANICH P., PAVARAJARN V. Photocatalytic degradation of diuron in microreactor, AIChE J. Article ID. 427520, 2015.

39. ZHANG Q., ZHANG Q., WANG H. LI Y. A high efficiency microreactor with $\mathrm{Pt} / \mathrm{ZnO}$ nanorod arrays on the inner wall for photodegradation of phenol. J. Hazard. Mater. 254-255 (1), 318, 2013.

40. PIERA E., CALPE J.C., BRILLAS E., DOMENECH X., PERAL J. 2, 4-dichlorophenoxyacetic acid degradation by catalyzed ozonation: $\mathrm{TiO}_{2} / \mathrm{UVA} / \mathrm{O}_{3}$ and $\mathrm{Fe}$ (II)/UVA/O Systems. Appl. Catal. B: Environ. 27, 169, 2000.

41. BUSCIO V., BROSILLON S., MENDRET J., CRESPI M., GUTIÉRREZ-BOUZÁN C. Photocatalytic membrane reactor for the removal of C.I. disperse Red 73. Materials. 8, 3633, 2015.

42. SEERY K.S., GEORGE R., FLORIS P., PILLAI S.C. Silver doped titanium dioxide nanomaterials for enhanced visible light photocatalysis. J. Photochem. Photobiol. A: Chem. 189, $258,2007$.

43. DONG Q., SU H., ZHNG D., LIU Z., LAI Y. Synthesis of hierarchical mesoporous titania with interwoven networks by eggshell membrane directed sol-gel technique. Micropor. Mesopor. Mat. 98, 344, 2007.

44. Dystar. Shade card of reactive dyes. Dystar Gmbh. Germany, 2000.

45. APHA. Standard Methods for the examination of water and wastewater. Am. Public Health Assoc. Washington D.C., 20 ${ }^{\text {th }}$ Edition 1998.

46. SONG S., SHENG Z., LIU Y., WANG H., WU Z. Influences of $\mathrm{pH}$ value in deposition-precipitation synthesis process on Pt-doped $\mathrm{TiO}_{2}$ catalysts for photocatalytic oxidation of NO. J. Environ. Sci. 24 (8), 1519, 2012.

47. GNANAPRAKASAM A., SIVAKUMAR V.M., THIRUMARIMURUGAN M. Influencing parameters in the photocatalytic degradation of organic effluent via nanometal oxide catalyst: a review. Indian J. Mater. Sci. Article ID 601827, 2015.

48. GÜMÜŞ D., AKBAL F. Photocatalytic degradation of textile dye and wastewater. Water Air Soil Poll. 216 (1), 117, 2011.

49. ARIMI A., FARHADIAN M., REZA A., NAZAR S., HOMAYOONFAL M. Assessment of operating parameters for photocatalytic degradation of a textile dye by $\mathrm{Fe}_{2} \mathrm{O}_{3} / \mathrm{TiO}_{2} /$ clinoptilolite nanocatalyst using taguchi experimental design. Res. Chem. Intermediat. 1-20, 2015.

50. ZHAO H., XU S., ZHONG J., BAO X. Kinetic study on the photocatalytic degradation of pyridine in $\mathrm{TiO}_{2}$ suspension systems. Catal. Today. 93-95, 857, 2004.

51. KANSAL S.K., KAUR N., SINGH S. Photocatalytic degradation of two commercial reactive dyes in aqueous phase using nanophotocatalysts. Nanoscale Res. Lett. 4, 709, 2009.

52. HU C., TANG Y.C., YU J.C., WONG P.K. Characterization and photocatalytic activity of nobelmetal- supported surface bond-conjugation $\mathrm{TiO}_{2} / \mathrm{SiO}_{2}$ for the destruction of azo dye. Appl. Catal. B: Environ. 40, 131, 2003.

53. HU C., WANG Y.Z., TANG H.X. Influence of adsorption on the photodegradation of various 441 dyes using surface bond-conjugated $\mathrm{TiO}_{2} / \mathrm{SiO}_{2}$ photocatalyst. Appl. Catal. B: Environ. 35, 95, 2001.

54. CHITRA S., PARAMASIVAN K., SINHA P.K., LAL K.B. Ultrasonic treatment of liquid waste containing ED TA. J. Clean Prod. 12, 429, 2004.
55. HONG LI., ZHAO G., SONG B., HAN G. Effect of incorporation of silver on the electrical properties of Sol-Gel-Derived Titanium Film. J. Cluster Sci. 19, 667, 2008.

56. ZOU J., CHEN C., LIU C., ZHANG Y., HAN Y., CUI L. $\mathrm{Pt}$ nanoparticles on $\mathrm{TiO}_{2}$ with novel metal - semiconductor interface as highly efficient photocatalyst. Mater. Lett. 59 (27), 3437, 2005.

57. POONGODI G., KUMAR R.M., JAYAVEL R. Structural, optical and visible light photocatalytic properties of nanocrystalline $\mathrm{Nd}$ doped $\mathrm{ZnO}$ thin films prepared by spin coating method. Ceram. Int. 41 (3), 4169, 2015.

58. LIU C.C., LAI P.F., LI C.H., KAO C.L. Photodegradation treatment of azo dye wastewater by $\mathrm{UV} / \mathrm{TiO}_{2}$ process. Dyes. Pigments. 12, 191, 2006.

59. BIZANI E., FYTIANOS K., POULIOS I., TSIRIDIS V. Photocatalytic decolorization and degradation of dye solutions and wastewaters in the presence of titanium dioxide. J. Hazard Mater. 136, 85, 2006.

60. REDDY S.S., KOTAIAH B. Decolorization of simulated spent reactive dye bath using solar / $\mathrm{TiO}_{2} / \mathrm{H}_{2} \mathrm{O}_{2}$. Int. J. Environ. Sci. Technol. 2, 245, 2005.

61. HASNAT M.A., SIDDIQUEY I.A., NURUDDIN A. Comparative photocatalytic studies of degradation of a cationic and an anionic dye. Dyes. Pigments. 66, 185, 2005.

62. BAHNEMANN D., BOCKELMANN D., GOSLICH R. Mechanistic studies of water detoxification in illuminated $\mathrm{TiO}_{2}$ suspensions. Sol. Energ. Mat. 24, 564, 1991.

63. KANEKO M., OKURA I. Photocatalysis: Science and Technology, Springer Berlin Heidelberg. 2002.

64. NAOI K., OHKO Y. TATSUMA T. Switchable rewritability of $\mathrm{Ag}-\mathrm{TiO}_{2}$ nanocomposite films with multicolor photochromism. Chem. Commun. 10, 1288, 2005.

65. CHEN W., ZHANG J., FANG Q. Sol-gel preparation of thick titania coatings aided by organic binder materials. Sens. Actuators B. 100 (1-2), 195, 2004.

66. SUBRAMANIAN V., WOLF E.E., KAMAT P.V. Semiconductormetal composite nanostructures: To what extent do metal nanoparticles improve the photocatalytic activity of $\mathrm{TiO}_{2}$ films?J. Phys. Chem. B. 105 (46), 11439, 2001.

67. D'OLIVEIRA J.C., AL-SAYYED G., PICHAT P. Photodegradation of 2- and 3-chlorophenol in $\mathrm{TiO}_{2}$ aqueous suspensions. Environ. Sci. Technol. 24, 990, 1990.

68. BARKA N., QOURZAL S., ASSABBANE A., AIT-ICHOU Y. Kinetic modeling of the photocatalytic degradation of methyl orange by supported $\mathrm{TiO}_{2}$. J. Environ. Sci. Eng. 4, $1,2010$.

69. LACHHEB H., PUZENAT E., HOUAS A., KSIBI M., ELALOUI E., GUILLARD C., HERRMANN J.M. Photocatalytic degradation of various types of dyes (alizarin $\mathrm{s}$, crocein orange g, methyl red, congo red, methylene blue) in water by UV Irradiated titania. Appl. Catal. B: Environ. 39, 75, 2002.

70. GUILLARD C., LACHEB H., HOUAS A., KSIBI M., ELALOUI E., HERRMANN J.M. Influence of chemical structure of dyes, of $\mathrm{pH}$ and of inorganic salts on their photocatalytic degradation by $\mathrm{TiO}_{2}$ comparison of the efficiency of powder and supported $\mathrm{TiO}_{2}$. J. Photochem. Photobiol. A: Chem. 158, 27, 2003.

71. 71. BHAKYA, S., MUTHUKRISHNAN, S., SUKUMARAN, M., MUTHUKUMAR. M, SENTHIL K. T., RAO M.V. Catalytic degradation of organic dyes using synthesized silver nanoparticles: a green approach. J. Biorem. Biodegrad. 6, 312, (2015).

72. TOOR A. P., VERMA A., JOTSHI C.K., BAJPAI P.K., SINGH, V. Photocatalytic degradation of direct yellow 12 
dye using $\mathrm{UV} / \mathrm{TiO}_{2}$ in a shallow pond slurry reactor. Dyes. Pigments. 68, 60, 2006.

73. MROWETZ M., PIROLA C., SELLI E. Degradation of organic water pollutants through sonophotocatalysis in the presence of $\mathrm{TiO}_{2}$. Ultrason. Sonochem. 10, 247, 2003.

74. SILVA C G., WANGAND W., FARIA J.L. Photocatalytic and photochemical degradation of mono-,di-,and tri-azo dyes in aqueous solution under UV irradiation. J.Photochem. Photobiol. A: Chem. 181 (2-3), 314, 2006.
75. FAISAL M., ABU TARIQ M., MUNEER M. Photocatalysed degradation of two selected dyes in UV-irradiated aqueous suspensions of titania. Dyes. Pigments. 72 (2), 233, 2007.

76. DEVADI A. H. M., KRISHNA M., MURTHY H.N.N., SATHYANARAYANA B.S. Statistical optimization for photocatalytic degradation of methylene blue by $\mathrm{Ag}-\mathrm{TiO}_{2}$ nanoparticles. procedia Mater. Sci. 5, 612, 2014. 